\title{
KARAKTERISTIK CEDERA DAN PENCARIAN PENGOBATAN PENYINTAS PASCA GEMPA BUMI 2009 DI KOTA PADANG
}

\author{
Mondastri Korib Sudaryo* \\ Email: maqo19@gmail.com
}

\begin{abstract}
ABSTRAK
Cedera akibat gempa bumi di Padang tahun 2009 dapat menimbulkan konsekuensi jangka panjang bagi para penyintas. Tujuan studi ini adalah mengetahui karakteristik cedera para penyintas serta perilaku pencarian pengobatan mereka pasca gempa bumi di Padang. Studi ini merupakan bagian dari studi kohort prospektif di kota Padang pada Januari-Agustus 2010, yang mengamati 277 penyintas yang tinggal di kota Padang, baik yang cedera (183) maupun yang tidak cedera (94). Studi ini diperkuat dengan studi kualitatif. Perbedaan proporsi secara statistic diuji dengan Chi-square. Diantara penyintas yang cedera, kasus patah tulang ditemukan 51 kasus $(27,7 \%)$. Patah tuilang terbanyak terjadi pada tungkai/kaki (58.8\%) dan lengan/tangan (21.6\%). Tujuan terbanyak dalam upaya mencari pertolongan pengobatan pertama kalinya adalah rumah sakit umum pemerintah dan swasta (masing-masing 31.4\%). Masih ada penyintas yang mendatangi dukun patah/tabib $(21.6 \%)$. Perbedaan proporsi upaya pencarian pengobatan pada kali pertama dan pada selanjutannya (kedua), secara statistik tidak bermakna (nilai-p > 0.05). Hampir semua penyintas masih menggunakan kursi roda (53\%) dan tongkat penyangga (41\%). Sebagian besar penyintas yang cedera mengalami patah tulang anggota gerak bawah. Tujuan terbanyak pencarian pengobatan adalah rumah sakit umum pemerintah dan swasta. Hampir semua penyintas penderita patah tulang masih harus hidup dengan alat bantu kursi roda atau tongkat penyangga.
\end{abstract}

Kata Kunci : cedera, patah tulang, gempa, Padang, pencarian pengobatan

\section{ABSTRACT}

Injury, due to earthquake in Padang, year 2009 may give survivors several long term consequences. The aim of this study was to know injury characteristics of the survivors and their treatment seeking behaviors after earthquake. This study was part of prospective cohort study in Padang city, January to August 2010, observing 277 survivors living in Padang, both injured (183) and not-injured (94). This study was strengthened with qualitative study. Proportion differences were statistically tested by Chi-square. Among injured survivors, fracture was found in 51 survivors $(27,7 \%)$. Fracturs were predominantly occurred in legs/feet $(58.8 \%)$ and arms/hands $(21.6 \%)$. The largest proportion of destination for treatment seeking for the first time after earthquake were government and private general hospitals (each $31.4 \%$ ). There were survivors visiting traditional fracture healer (21.6\%). Proportion differences between first and next (second) treatment seeking were statistically not significant ( $p$-value $>0.05$ ). Almost all survivors were still using wheel chair (53\%) and supporting stick $(41 \%)$. Majority of injured survivors experienced fractures of lower extremities. Predominant destination for treatment seeking were government and private general hospitals. Almost all survivors with fractures still had to live with wheel chair and supporting stick.

Key words: injury, fracture, earthquake, Padang, treatment seeking

\section{PENDAHULUAN}

Indonesia merupakan salah satu negara yang paling rentan mengalami bencana alam. Dalam lingkup global per tahun 2018, Indonesia masuk dalam 10 negara teratas yang paling sering mengalami bencana alam (Guha-Sapir, Hoyois, Wallemacq, Below, 2016;

*. Dep. Epidemiologi, Fakultas Kesehatan Masyarakat Univeristas Indonesia 
Centre for Research on the Epidemiology of Disasters (CRED), 2017) bahkan menjadi negara dengan jumlah kematian terbanyak akibat bencana (Guha-Sapir, 2018). Salah satu bencana terbesar setelah tsunami Aceh tahun 2004 adalah gempa bumi di Sumatra Barat pada tahun 2009.

Pada tanggal 30 September 2009, pantai Padang di Sumatra Barat dihantam gempa bumi pada jam 17:16 pm waktu setempat. Gempa berukuran 7.6 skala Richter merusak 11 kabupaten/kota (dari 19 kabupaten. Kota di Sumatra Barat). Tujuh dari 11 Kabupaten/ Kota rusak berat, termasuk kota Padang (World Health Organization (WHO), 2009.a). Dilaporkan 279,201 rumah and 292 fasilitas kesehatan rusak dengan deajat kerusakan yang berbedabeda (WHO, 2009.b). Jumlah total penduduk Padang yang terdampak mencapai 1,2 juta orang. Per 28 Oktober $2009,1,117$ orang dilaporkan meninggal dan 3,515 orang mengalami cedera. (WHO, 2009.b).

Cedera yang timbul akibat gempa bumi yang sangat kuat biasaya cukup serius dan dapat menimbulkan konsekuensi jangka panjang bagi para penyintas seperti timbulknya keterbatasan fungsi fisik (disabilitas), gangguan fisik dan mental yang kronis, masalah social-ekonomi dan pada akhirnya dapat menimbulkan penurunan kualitas hidup penyintas.

Artikel ini menyajikan hasil pengamatan di bagian awal (at baseline) dari sebuah studi longitudinal di kota Padang yang sudah dipublikasikan di jurnal internasional pada tahun 2012 (Sudaryo et al., (2012). Tujuan pengamatan studi di bagian awal (at baseline) ini adalah untuk mendapatkan gambaran tentang karakteristik cedera dan patah tulang para penyintas serta perilaku pencarian pengobatan mereka pasca gempa bumi di Padang.

\section{METODE PENELITIAN}

Sebagaimana sudah disebutkan sebelumnya studi ini merupakan bagian dari sebuah studi longitudinal dengan desain observasional kohort prospektif di kota Padang yang dilaksanakan mulai Januari sampai Agustus $2010 . \quad$ Untuk mendukung hasil studi kohort ini, studi kualitatif dengan metode pengumpulan data wawancara mendalam (indepth interview) juga dilakukan pada beberapa informan kunci seperti staf dinas terkait, tokoh masyarakat, dan beberapa penyintas.

Studi kohort ini mengamati 277 subyek penyintas pasca gempa Padang yang tinggal menetap di kota Padang, baik yang cedera (183 subyek) maupun yang tidak cedera (94 subyek), selama 7 bulan,. Anggota kohort yang cedera diidentifikasi dari kompilasi data korban cedera di Dinas Kesehatan kota Padang, 5 rumah sakit umum di kota Padang dan LSM Handicap International. Data penyintas yang mengalami cedera ini kemudian dilacak sampai menemukan alamat rumah mereka. Anggota kohort penyintas yang tidak cedera dipilih secara acak sederhana dari lingkungan tetangga terdekat dari rumah penyintas yang cedera di wilayah yang sama.

Penjelasan detil dari studi kohort ini yang terkait perancangan desain, populasi studi dan analisis data dapat dibaca dalam bab metodologi dari artikel yang sudah kami publikasikan di jurnal Global Health Action (Sudaryo et al., (2012). Khusus untuk tujuan penulisan artikel ini pada masa pengamatan di awal studi (at baseline) selain gambaran karakteristik sosiodemorafis dan cedera, pada kelompok penyintas yang mengalami patah tulang juga digali pola perilaku pencarian pengobatan pasca gempa. Wawancara untuk mengukur dan merekam karakteristik sosio-demografis, jenis cedera dan patah tulang (fracture), pola pencarian pengobatan dilakukan secara tatap muka dengan pewawancara terlatih dengan menggunakan kuesioner standar yang telah teruji (Sudaryo et al., (2012).

Pemasukan data menggunakan EpiData dan dianalisis dengan SPSS. Data dianalisis secara univariat dan bivariat. Perbedaan proporsi variabelvariabel sosio-demografi pada kelompok cedera dan kelompok tidak cedera dan perbedaan proporsi perilaku pencarian pengobatan fase pertama dan pada fase selanjutnya ditentukan kemaknaan statistiknya dengan uji Chi-square. Perbedaan proporsi dengan nilai $\mathrm{p}<$ 0,05 dianggap secara statistic bermakna (signifikan) 
Studi ini telah lolos kaji etik dan mendapat ethical clearance dari Komite Etik Fakultas Kesehatan Masyarakat, Universitas Indonesia

\section{HASIL}

\section{Karakteristik Sosio-demografi}

Hasil studi dalam Tabel.1 menunjukkan bahwa sebagian besar populasi pada kedua kelompok (cedera maupun non-cedera) adalah perempuan (72.9\%), usia $18-59$ tahun (84.8\%), berstatus sudah menikah $(72.2 \%)$, memiliki keluarga berukuran sedang, yaitu 4-6 orang per keluarga (56.3\%), pendidikan SMA ke atas (51.3\%), berstatus pelajar atau tidak bekerja atau ibu rumah tangga (63.2\%). Khusus untuk pendidikan, pada kelompok cedera sebagian besar berpendidikan rendah, SMP ke bawah (50.5\%) sementara pada kelompok yang tidak cedera sebagian besar berpendidikan cukup tinggi yaitu SMA ke atas (54.8\%). Perbedaan proporsi seluruh variabel sosiodemografi pada kelompok cedera dan kelompok tidak cedera secara statitistik tidak bermakna, kecuali pada variabel status pernikahan (nilai $\mathrm{p}<0.05$ )

Tabel 1

Karakteristik Sosio-demografi pada Awal Studi Pasca Gempa Padang 2009

\begin{tabular}{|c|c|c|c|c|c|c|c|}
\hline \multirow{2}{*}{$\begin{array}{c}\text { Variabel } \\
\text { Sosio-demografi }\end{array}$} & \multicolumn{2}{|c|}{$\begin{array}{l}\text { Cedera } \\
(n=184)\end{array}$} & \multicolumn{2}{|c|}{$\begin{array}{c}\text { Tidak cedera } \\
(n=93)\end{array}$} & \multicolumn{2}{|c|}{$\begin{array}{c}\text { Total } \\
(n=277)\end{array}$} & \multirow[t]{2}{*}{ Nilai p* } \\
\hline & Frekuensi & $\%$ & Frekuensi & $\%$ & Frekuensi & $\%$ & \\
\hline \multicolumn{8}{|l|}{ Jenis Kelamin } \\
\hline Laki-laki & 53 & 28.8 & 22 & 23.7 & 75 & 27.1 & 0.36 \\
\hline Perempuan & 131 & 71.2 & 71 & 76.3 & 202 & 72.9 & \\
\hline \multicolumn{8}{|l|}{ Umur (tahun) } \\
\hline $18--39$ & 79 & 43 & 41 & 44.1 & 120 & 43.3 & 0.68 \\
\hline $40--59$ & 73 & 39.6 & 42 & 45.2 & 115 & 41.5 & \\
\hline $60+$ & 32 & 17.4 & 10 & 10.7 & 42 & 15.2 & \\
\hline \multicolumn{8}{|l|}{ Status Pernikahan } \\
\hline Menikah & 124 & 67.4 & 76 & 81.7 & 200 & 72.2 & 0.01 \\
\hline $\begin{array}{l}\text { Tidak menikah } \\
\text { (bujangan/janda/duda) }\end{array}$ & 60 & 32.7 & 17 & 18.3 & 77 & 27.8 & \\
\hline \multicolumn{8}{|l|}{ Ukuran rumah tangga } \\
\hline Kecil ( $1-3$ orang) & 33 & 17.9 & 22 & 23.7 & 55 & 19.9 & 0.48 \\
\hline Sedang (4-6 orang) & 107 & 58.2 & 49 & 52.6 & 156 & 56.3 & \\
\hline Besar (7+ orang) & 44 & 23.9 & 22 & 23.7 & 66 & 23.8 & \\
\hline \multicolumn{8}{|l|}{ Pendidikan } \\
\hline$<=$ SMP & 93 & 50.5 & 42 & 45.2 & 135 & 48.7 & 0.4 \\
\hline SMA/ Perguruan Tinggi & 91 & 49.5 & 51 & 54.8 & 142 & 51.3 & \\
\hline \multicolumn{8}{|l|}{ Pekerjaan } \\
\hline PNS / Pedagang & 21 & 11.4 & 3 & 3.2 & 24 & 8.7 & 0.08 \\
\hline Buruh kasar/ Tukang & 14 & 7.6 & 8 & 8.6 & 22 & 7.9 & \\
\hline $\begin{array}{l}\text { Ibu rumah tangga/ } \\
\text { pelajar/ tidak bekerja }\end{array}$ & 117 & 63.6 & 58 & 62.4 & 175 & 63.2 & \\
\hline Lainnya & 32 & 17.4 & 24 & 25.8 & 56 & 20.2 & \\
\hline
\end{tabular}

\section{Karakteristik Cedera}

Dari 184 orang responden penyintas yang cedera, kasus patah tulang (fracture) ditemukan sebanyak 51 kasus $(27,7 \%)$. (Tabel.2.) Jenis cedera lainnya selain patah tulang yang tercatat dalam studi ini (sebanyak $72.3 \%$ ) mencakup dislokasi, luka robek atau luka tusuk, memar, luka bakar dll. (tidak ditampilkan dalam tabel).
Di antara kasus-kasus patah tulang, jenis yang terbanyak dialami penyintas adalah patah pada bagian angota gerak yaitu tungkai atau kaki $(58.8 \%)$ dan lengan atau tangan $(21.6 \%)$. Cedera patah pada tulangtulang yang vital yaitu tulang penyangga tubuh (tulang belakang/ punggung) dan tulang kepala/ leher ditemukan masingmasing sebanyak $15.7 \%$ (Tabel.3). 
Tabel 2

Jenis Cedera Responden pada Awal Studi Pasca Gempa Padang 2009

\begin{tabular}{lrr}
\hline Jenis Cedera & Frekuensi & Proporsi (\%) \\
\hline Cedera patah tulang (fracture) & 51 & 27.7 \\
Cedera lain (non-fracture) & 133 & 72.3 \\
\hline Total & 184 & 100.0 \\
\hline
\end{tabular}

Tabel 3

Jenis Patah Tulang Penyintas pada Awal Studi Pasca Gempa Padang 2009

\begin{tabular}{crr}
\hline Jenis Patah Tulang (Fracture) & $\begin{array}{c}\text { Frekuensi } \\
(\mathbf{n = 5 1 )}\end{array}$ & $\begin{array}{c}\text { Proporsi } \\
(\mathbf{\%})\end{array}$ \\
\hline Patah tulang kepala dan leher & 8 & \\
Ya & 43 & 15.7 \\
Tidak & & 84.3
\end{tabular}

Patah tulang muka

Ya 2

Tidak 49

96.1

Patah tulang dada dan iga

Ya

7.8

Tidak 47

92.2

Patah tulang perut

Ya 2

3.9

Tidak 49

96.1

Patah tulang punggung/ tulang belakang

Ya

Tidak

Patah tulang lengan/ tangan

Ya

11

21.6

Tidak

40

78.4

Patah tulang tungkai/ kaki

Ya

30

58.8

Tidak

41.2

\section{Perilaku Pencarian Pegobatan}

(Health Seeking Behavior)

Dari Tabel.4. tampak bahwa diantara 51 orang penyintas yang mengalami patah tulang, tujuan terbanyak dalam upaya yang pertama kalinya untuk mencari pertolongan pengobatan adalah rumah sakit umum pemerintah dan rumah sakit umum swasta, masing-masing sebanyak $31.4 \%$. Diantara penyintas masih cukup banyak yang mendatangi dukun patah atau ustadz atau tabib untuk mengobati patah tulang mereka (21.6\%). Ketika masalah kesehatan yang dialami penyintas patah tulang masih berlanjut, tujuan berikutnya/ selanjutnya yang terbanyak untuk mencari pengobatan masih rumah sakit umum (39.2\%) dan rumah sakit swasta (27.5\%). Proporsi mereka yang mendatangi dukun patah atau ustadz atau tabib pada upaya lanjutan ini menurun menjadi $13.7 \%$. Perbedaan proporsi seluruh upaya pencarian pengobatan pada kali pertama dan pada kali kedua (lanjutan) secara statistik tidak bermakna (nilai-p $>0.05$ ). 
Table 4

Tujuan Pencarian Pengobatan bagi Penyintas dengan Cedera Patah Tulang Pada Awal Studi Pasca Gempa Padang 2009

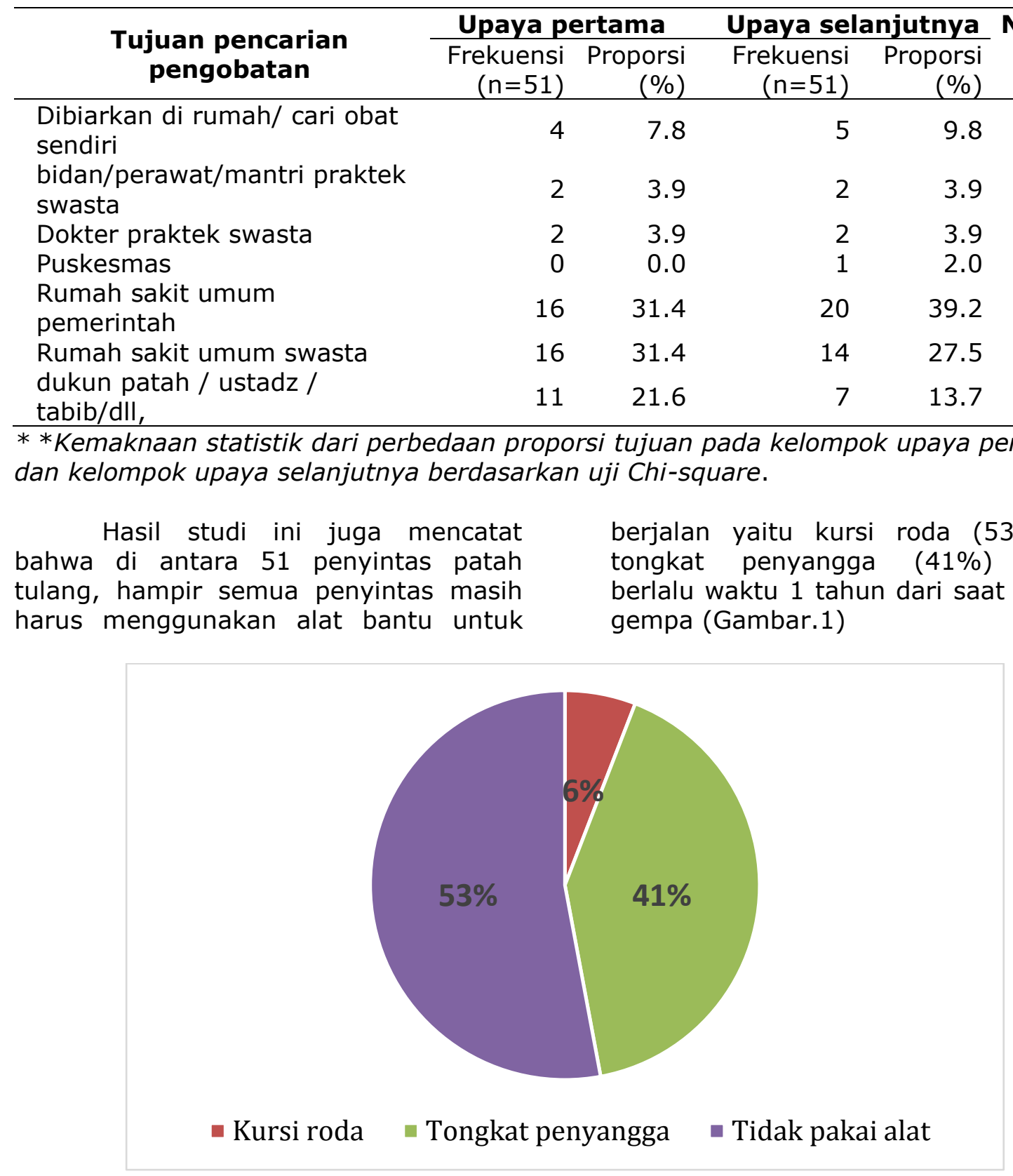

Gambar 1

Pemakaian Alat Bantu Responden Patang Tulang Pasca Gempa Padang, $2009(n=51)$

\section{PEMBAHASAN}

Temuan kami menunjukkan bahwa mayoritas penyintas yang mengalami cedera adalah perempuan. Hal ini konsisten dengan temuan dari studi-studi lain di luar negeri (Armenian etal., 1992; Bulut et al., 2005; Sami et al., 2009; Peek-Asa et al., 2003; Petal, 2004). Hal ini mungkin disebabkan perempuan lebih banyak yang tinggal di rumah sebagai ibu rumah tangga. Karena kejadian gempa terjadi jam 5 sore maka besar kemungkinan lelaki masih bekerja atau dalam perjalanan pulang menuju rumah sementara perempuan ibu-ibu rumah tangga sebagian besar memang berada di rumah pada saat itu.

Terkait dengan umur, proporsi subyek lansia (lanjut usia, >= 
60 tahun) pada kelompok penyintas yang cedera (17.4\%) lebih tinggi dibandingkan proporsi lansia pada kelompok yang non-cedera (10.7\%). Hal ini dapat dimengerti mengingat kelompok populasi lansia lebih rentan untuk cedera disebabkan keterbatasan atau kemunduran fungsi fisik dan psikososial. Hasil pengamatan ini sejalan dengan hasil studi kajian pustaka sistematik (systematic literature review) yang menelaah berbagai artikel ilmiah yang diterbitkan di jurnal ilmiah internasional di seluruh dunia yang terdaftar dalam basis data publikasi ilmiah MEDLINE, Pub Med, Science direct, and the Scopus and Cochrane libraries, sejak tahun 2000 to 2017 Bayraktar \& Yilmaz, 2018).

Terkait dengan status pekerjaan, proporsi subyek dengan berstatus PNS atau pedagang pada kelompok penyintas yang cedera $(11.4 \%)$ jauh lebih tinggi dibandingkan proporsi PNS/ pedagang pada kelompok yang non-cedera (3.2\%). Perbandingan ini mengindikasikan risiko untuk mengalami cedera yang lebih tinggi hampir 4 kali lipat, bagi PNS/ pedagang dibandingkan pada mereka yang bukan PNS/ pedagang. Peningkatan risiko ini mungkin dikarenakan pada jam kerja, sebagian besar PNS atau para pedagang masih berada di kantor atau toko mereka. Sebaliknya penyintas pada kelompok cedera lebih rendah proporsinya yang bekerja sebagai buruh kasar atau tukang (7.6\%) dibandingkan proporsi pekerja buruh/ tukang pada penyintas noncedera $(8.6 \%)$. Mungkin ini dikarenakan lebih sedikit buruh kasar atau tukang yang bekerja di dalam gedung atau tempat tertutup.

Untuk variabel pendidikan,
tampak bahwa proporsi penyintas berpendidikan rendah, tingkat SMP ke bawah (50.5\%) lebih tinggi pada kelompok cedera dibandingkan proporsi pendidikan rendah pada kelompok noncedera (45.2\%). Hal ini juga mengindikasikan peningkatan risiko cedera pada subyek berpendidikan rendah dibanding yang berpendidikan tinggi. Peningkatan risiko ini dapat terkait dengan pengetahuan umum tentang kesiapsiagaan menghadapi bencana yang lebih rendah pada mereka yang pendidikannya lebih rendah. Hasil ini sejalan dengan hasil studi di Iran yang menunjukkan adanya hubungan yang bermakna antara tingkat pendidikan dan pengetahuan yang rendah dengan rendahnya kemampuan melakukan tindakan praktis untuk mengurangi dampak merugikan jika terjadi gempa bumi (Ostad Taghizadeh, Hosseini, Navidi, Mahaki, Ammari, \& Ardalan, 2012).

Dalam temuan kami sebagian besar cedera adalah cedera ringan yang mencakup memar, , luka robek atau luka tusuk dan dislokasi. sementara proporsi patah tulang hanya sekitar $28 \%$, tidak lebih dari sepertiga dari keseluruhan kasus cedera. Jenis kasus patah tulang yang terbanyak dialami penyintas dalam studi ini adalah patah pada bagian angota gerak bawah yaitu tungkai atau kaki (58.8\%). Hal ini sangat sesuai dengan hasil kajian pustaka sistematik (systematic literature review) dari kumpulan artikel jurnal ilmiah internasional dari negara-negara berkembang yang mengalami bencana gempa bumi besar sejak tahun 1970 sampai Juni 2016 (MacKenzie et al., 2017). Kajian pustaka sistematik ini juga menyimpulkan bahwa 59\% dari 3988 patah tulang yang dilaporkan dari berbagai artikel yang dikaji terjadi pada anggota gerak bawah (tungkai dan kaki).

Hasil studi kami menunjukkan bahwa setelah terjadinya cedera patah tulang masih ada keterlambatan (delay) untuk mencari pertolongan pengobatan ke fasilitas layanan kesehatan (fasyankes) yang tepat. Sebagian penyintas patah tulang tidak langsung mencari rumah sakit atau dokter atau tenaga medis lainnya melainkan tidak berbuat apa-apa di rumah atau membeli obat sendiri atau bahkan masih cukup banyak (sekitar 22\%) yang mencari pertolongan kepada pihak yang bukan tenaga medis professional seperti dukun patah, ustadz, tabib, dll. Namun pada fase upaya pencarian pengobatan selanjutnya (ketika pencarian pertolongan pertama tidak membuahkan hasil) penyintas sudah lebih banyak yang memanfaatkan fasyankes yang tepat sebagaimana tampak pada menurunnya proporsi penyintas yang 
pergi ke pengobantan alternatif (dukun patah, ustadz, tabib, dll) dan lebih timgginya proporsi yang datang ke rumah sakit umum.

Hasil studi kualitatif yang melengkapi studi kohort ini, yang dilakukan melalui wawancara mendalam, menggambarkan bahwa ada responden penyintas yang menderita patah tulang yang menunda sampai 4 (empat) hari untuk mencari pertolongan di fasyankes karena beberapa kendala seperti kondisi cuaca, tidak ada uang, dan menunggu sampai dapat ambulans.

"...pertama mau dilarikan ke Rumah Sakit. Tapi takut tsunami, saya dan kawan-kawan lari pake motor kawan. Karena mau ke rumah sakit kan, nggak bisa, hujan malam tu. Sekitar jam 3 malam baru berhenti hujan. Mau ke rumah sakit kan, karena uang nggak ada, kemudian cari ambulans, baru kita ke rumah sakit hari Sabtu siang... Gempa kan Rabu sore, sudah tiga hari baru ke rumah sakit...

\section{(Penyintas laki-laki, 48 tahun)}

Selama penundaan ini penyintas memilih untuk diurut, sementara dengan kasus patah tulangnya penyintas mengalami perdarahan yang berindikasi medis untuk dioperasi.

"...Sebelum ke rumah sakit, diurut aja... ...di rumah sakit sepuluh hari, masuk hari sabtu tanggal 12, pendarahan belum berkurang...

...Karena, waktu pertama ke M. Djamil. Di M. Djamil di rongsen. Dibilang dipasang pen 7 katanya kan. Entah apa yang nggak ada disitu, akhirnya di kirim ke RST sore hari sekitar jam empat. Jam sembilan langsung di operasi.."

\section{(Penyintas laki-laki, 48 tahun)}

Masalah perilaku pencarian pengobatan penyintas menuju fasyankes yang tepat dapat terkait dengan kondisi klinis (seperti tingkat keparahan cedera patah tulang) yang mempengaruhi mobilitas penyintas, seberapa dekat dan mudah akses atau jangkauan ke layanan fasyankes serta peran serta aktif masyarakat sekitar sebagai penolong pertama (first responder). Tidak semua korban dengan kondisi klinis tertentu dapat segera menjangkau fasyankes di lingkungan tempat tinggal mereka. Dalam situasi ekstrim akibat bencana, dapat pula dimengerti kemungkinan adanya keterbatasan manajemen layanan kesehatan tertentu misalnya terkait dana dan prasarana alat kesehatan (alkes), yang mungkin dapat mempengaruhi kemampuan atau fungsi fasyankes untuk secara cepat menemukan dan memberikan pertolongan kepada penyintas. Masalah ini menjadi faktor yang juga penting ketika fasyankes utama (seperti rumah sakit umum provinsi $M$. Jamil) turut terdampak secara fisik akibat gempa. Hasil wawancara mendalam dengan staf dinas terkait menyiratkan kemungkinan tersebut.

"...waktu itu kan dari menteri kesehatan dikatakan semua korban gempa itu akan gratis, Rumah sakit swasta pun silahkan layani juga. Jadi saya gak ada masalah. Cuman pada hari ke dua, tiga dan empat nggak ada oksigen waktu itu...

... Kalau SDM nggak ada masalah. Kita sudah banyak latihan PPGD, Latihan LCLS, semua sudah banyak, dokterdokter kita disiapkan untuk itu. Cuman sekarang dananya nggak ada..."

\section{(Staf dinas, perempuan, 58 tahun)}

Dengan segala keterbatasan fasyankes dan kesulitan kondisi korban penyintas, dalam situasi yang ekstrim akibat bencana, peran serta aktif masyarakat termasuk LSM sebagai penolong pertama (first responder) akan sangat membantu mendekatkan korban penyintas kepada fasyankes, sebagaimana juga diungkapkan staf di atas.

"...kalau LSM itu yang saya tahu bagaimana membantu yang tadi tuh, misalnya mengantar mereka ke tempat pelayanan kesehatan, perawatan lukanya. Kalau mengantar mereka ke puskesmas kan. Itu saja baru. Kalau mereka gak bisa datang, baru kita mengunjungi..."

\section{(Staf dinas, perempuan, 58 tahun)}

Studi ini juga menunjukkan bahwa setelah setahun berlalu pasca gempa, hampir semua $(94 \%)$ dari 
penyintas penderita patah tulang masih harus hidup dengan topangan alat bantu kursi roda atau tongkat penyangga. Disabilitas ini tentu akan berdampak pada kualitas hidup mereka dalam jangka panjang sebagaimana telah dibuktikan dalam studi kohort selama 7 bulan di kota Padang yang telah kami publikasikan (Sudaryo et al., (2012).Studi di kalangan penyintas pasca bencana gempa Sichuan di China juga menunjukkan bahwa penyintas yang cedera tulang belakang cenderung merasa kualitas hidup mereka rendah (Tasiemski, Nielsen, \& Wilski, 2010)

Kelemahan dari studi ini adalah bahwa banyak profil klinis dan tatalaksana dari kasus cedera dan patah tulang yang tidak terdokumentasi dengan lengkap. Salah satu sebabnya adalah hilang atau rusaknya rekam medik pasien di rumah sakit umum di Padang yang terdampak gempa. Wawancara mendalam juga tidak mudah dalam situasi bencana, khususnya terkait hal-hal yang sensitif dalam manajemen dan kebijakan kesehatan di dinas terkait di kota Padang.

\section{SIMPULAN}

Sebagian besar dari penyintas cedera pasca gempa Padang mengalami patah tulang pada anggota gerak bawah yaitu tungkai atau kaki. Pendidikan penyintas yang rendah cenderung meningkatan risiko cedera. Tujuan terbanyak pencarian pengobatan pasca gempa dari penyintas adalah rumah sakit umum pemerintah dan swasta. Walaupun demikian masih ada penyintas yang tidak pergi berobat atau mencari pengobatan sendiri dan masih cukup banyak yang pergi ke pengobatan alternatif seperti dukun patah atau tabib. Setelah setahun berlalu pasca gempa, hampir semua penyintas penderita patah tulang masih harus hidup dengan topangan alat bantu kursi roda atau tongkat penyangga.

\section{SARAN}

Program KIE (komunikasi, informasi dan edukasi) yang efektif sangat mendesak untuk dikembangkan dan diperkuat dalam rangka meningkatkan pengetahuan tentang:
1. risiko dan dampak kesehatan akibat gempa dan sekaligus juga ancaman bencana lainnya (multi-hazard) di kota Padang

2. upaya mitigasi dan kesiapsiagaan bencana pada populasi rentan di kota Padang

3. upaya pencarian pengobatan yang tepat di fasyankes yang sesuai

Hal ini sangat sesuai dengan prioritas pertama kerangka kerja global Sendai (Sendai framework) yaitu pemahaman yang tepat akan risiko bencana. Disampig itu KIE yang efektif adalah juga merupakan bagian penting dari program pengurangan risiko bencana (PRB) dan penguatan ketangguhan (resilience) bencana di kalangan masyarakat umum kota Padang khususnya dan provinsi Sumatera Barat pada uumnya. Termasuk sebagai bagian dari KIE adalah integrasi edukasi kebencanaan ke dalam kurikulum sekolah dan perguruan tinggi serta pelatihan-pelatihan di tempat kerja dengan metode dan media yang atraktif dan interaktif.

Program rehabilitasi jangka panjang yang melibatkan peran serta masyarakat dan LSM secara aktif serta penyediaan infrastruktur atau sarana khusus oleh Pemda Kota Padang utk penyintas difabel perlu secara serius disiapkan dan dijalankan untuk mengurangi disabilitas dan meningkatkan kualitas hidup penyintas yang menyandang keterbatasan

\section{Ucapan terima kasih}

Studi ini dapat dilakukan dengan dana hibah dari the European Commission under the 6th Framework Programme Contract n8 GOCE-CT-2007036877.

Kami mengucapkan banyak terima kasih kepada berbagai pihak yang mendukung terlaksananya studi ini, yaitu Pemerintah Daerah Kota Padang, Dinas Kesehatan Kota Padang dan Provinsi Sumatra Barat, Rumah Sakit Umum (RSU) M. Jamil, Rumah Sakit Daerah (RSUD) Kota Padang, RSU Siti Rahmah, RSU Yos Sudarso dan RSU Ibnu Sina. 


\section{DAFTAR PUSTAKA}

Bayraktar N., \& Yilmaz, UD. (2018). Vulnerability of elderly people in disasters: a Systematic review. Turkish Journal of Geriatrics, 21(3), 467-482. DOI: 10.31086/tjgeri.2018344062

Bulut, M., Fedakar, R., Akkose, S., Akgoz, S., Ozguc. H., \& Tokyay, R. (2005). Medical experience of a university hospital in Turkey after the 1999 Marmara earthquake. Emerg Med J, 22, 494-498.

Centre for Research on the Epidemiology of Disasters (CRED)., Université Catholique de Louvain (UCL)., \& USAID (2017). Natural disaster 2017. Annual disaster statistical review 2017. Brussels, Belgium: CRED, UCL.

Guha-Sapir, D., Hoyois, Ph., Wallemacq, P., Below, R. (2016). Annual Disaster Statistical Review 2016: the Numbers and trends. Brussels, Belgium: CRED, UCL.

Guha-Sapir, D (2018), Review of disaster events. Supplementary information. Brussels, Belgium: CRED, UCL.

Armenian, HK., Noji, EK., \& Oganesian, AP., (1992). A case - control study of injuries arising from the earthquake in Armenia, 1988. Bulletin of the World Health Organization, 70(2), 251-257

MacKenzie, JS., Banskota, B., Sirisreetreerux, N., Shafiq, B., \& Hasenboehler EA (2017). A Review of the Epidemiology and Treatment of Orthopaedic Injuries After Earthquakes in Developing Countries. World Journal of Emergency Surgery. 12:9 DOI 10.1186/s13017-017-0115-8

Ostad Taghizadeh, A., Hosseini, M., Navidi, I., Mahaki, AA., Ammari, H., \& Ardalan, A. (2012). Knowledge, Attitude and Practice of Tehran's Inhabitants for an Earthquake and Related Determinants. PLoS currents. 4. e4fbbbe1668eef.

10.1371/4fbbbe1668eef.
Peek-Asa., C., Ramirez, M., Seligson H., \& Shoaf K., (2003). Seismic, structural, and individual factors associated with earthquake related injury. Injury Prevention, 9, 62-66

Petal, MA, (2004). Urban disaster mitigation and preparedness: the 1999 Kocaeli earthquake. A dissertation submitted in partial satisfaction of the requirements for the degree Doctor of Philosophy in Urban Planning.

Sami, F., Ali, F., Zaidi, SHH., Rehman, H., Ahmad T., \& Siddiqui, MI (2009). The October 2005 Earthquake in Northern Pakistan: Pattern of Injuries in Victims Brought to the Emergency Relief Hospital, Doraha, Mansehra. Prehospital and Disaster Medicine http://pdm. medicine. wisc.edu Vol. 24,No. 6.

Sudaryo, MK, Besral, Endarti, AT, Rivany, R, Phalkey, R, Marx, M, Guha-Sapir, D (2012). Injury, disability and quality of life after the 2009 earthquake in Padang, Indonesia: a six-month prospective cohort study of adult survivors. Global Health Action. 2012, 5: 11816 http://dx.doi.org/10.3402/gha.v5 i0.11816.

Tasiemski, T., Nielsen, S., \& Wilski, M. (2010). Quality of Life in People with Spinal Cord Injury Earthquake Survivors From Sichuan Province in China. Asia Pacific Disability Rehabilitation Journal, Vol. 21 No. 2.

World Health Organization (2009.a.). Emergency and humanitarian action (eha), WHO Indonesia. Earthquake in Padang, West Sumatra Province, Republic of Indonesia. Emergency Situation Report (ESR -1)

World Health Organization (2009.b.). Emergency and Humanitarian Action (EHA), WHO Indonesia. Earthquake in Padang, West Sumatra Province, Republic of Indonesia. Emergency Situation Report (ESR -15) 